\title{
JURISDICTION AND ENFORCEMENT POST BREXIT
}

\author{
ERIK LAGERLÖF*
}

\begin{abstract}
In the context of international business and commercial transactions, it is vital that the judgments of one State are enforced by the courts in another. EU law has played a significant role in revolutionising the rules applicable to jurisdiction and enforcement in a cross-border context. As a Member State, the UK has benefitted from these rules and they have contributed to the position of the UK and, in particular, London as the leading centre for dispute resolution in Europe, if not worldwide. With the purpose of contributing to the ongoing discussion concerning common $E U$ and UK rules on jurisdiction and enforcement of judgments post Brexit more broadly, this article provides an updated view of the major issues involved. In doing so, it also underlines the importance of a common EU-UK framework in this regard and the urgency for the EU and $U K$ negotiators to agree on a sensible way forward.
\end{abstract}

\section{INTRODUCTION}

The effective enforcement of judgments is fundamental to a functioning society and necessary for the rule of law to exist. If a contract cannot ultimately be enforced, it becomes a meaningless piece of paper. In the context of international business and commercial transactions, it is vital that the judgments of one State are enforced by the courts in another. EU law has played a significant role in revolutionising the rules applicable to jurisdiction and enforcement in a cross-border context. ${ }^{1}$ These rules have helped the UK to export the use of its judicial system and the decisions resulting from their courts. Thus, as a Member State, the UK has benefitted from these rules and they have contributed to the position of the UK and, in particular, London as the leading centre for dispute resolution in Europe, if not worldwide.

The rules governing jurisdiction and enforcement amongst EU Member States are presently governed by Regulation (EU) No 1215/2012 of the European Parliament and of the Council of 12 December 2012 on jurisdiction and the recognition and enforcement of judgments in civil and commercial matters [2012] OJ L351/1 (the BIR (Recast)). ${ }^{2}$ The EU is also a party to international agreements governing jurisdiction and enforcement with third countries, notably the Lugano Convention of 30 October 2007 on jurisdiction and the recognition and enforcement of judgments in civil and commercial matters (Lugano Convention 2007) and the Hague Convention of 30 June 2005 on Choice of Court Agreements (Hague Convention). Following the British decision to leave the EU, with the UK no longer subject to EU law and not covered by international agreements concluded by the EU alone, the future application of these rules to the UK are uncertain. Without an

\footnotetext{
*Senior Manager at Vinge, Adjunct Professor of Law at the Stockholm School of Economics, Visiting Fellow at St Edmund's College (Cambridge University).

1 The term "jurisdiction" is here used in a private international law context, referring to the power of courts, as opposed to the public international law concept of jurisdiction, which essentially encompasses any exercise of regulatory power.

${ }^{2}$ Denmark is subject to the BIR (Recast) through an international agreement (see further text to $\mathrm{n} 13$ below).
} 
effective legal framework for jurisdiction and the enforcement of judgments to govern relationships between the EU and the UK, there is a serious risk to UK citizens, businesses, institutions and the UK government to have judgments which they have obtained in the UK courts effectively enforced, and to have the jurisdiction of UK courts recognised, throughout the EU. Such a development may well affect the premier position enjoyed by the UK, with the economic consequences that follow. An effective regime to govern jurisdiction and enforcement between the parties is also in the interest of EU Member States and their citizens and businesses engaged in trading and interacting with the UK.

This contribution considers the impact of Brexit on the BIR (Recast), the Lugano Convention 2007 and the Hague Convention, including how they are affected by the Agreement of 19 October 2019 on the withdrawal of the United Kingdom of Great Britain and Northern Ireland from the European Union and the European Atomic Energy Community (Withdrawal Agreement). The purpose is not to provide a detailed picture of these instruments, but to give the reader an understanding of their current and future post Brexit status and some of their key characteristics in order to portray the issues involved.In addition to these three instruments, the standing of the Brussels Convention on jurisdiction and the enforcement of judgments in civil and commercial matters (Brussels Convention), a predecessor to the BIR (Recast), will be considered. In view of the uncertainty surrounding private international law post Brexit, several prominent commentators have argued that the Brussels Convention has been revived upon the British exit such that the EU Member States would be bound to recognise and enforce judgments under this convention vis-à-vis the UK (a similar argument could be made with regard to the Lugano Convention of 16 September 1988 on jurisdiction and the enforcement of judgments in civil and commercial matters (Lugano Convention 1988)). ${ }^{3}$ In this article, it is argued that the Brussels Convention has not been brought back to life by Brexit and cannot be considered as an alternative future legal framework.

With the purpose of contributing to the ongoing discussion concerning common EU and UK rules on jurisdiction and enforcement of judgments post Brexit more broadly, this article provides an updated view of the major issues involved. In doing so, it also underlines the importance of a common EU-UK framework in this regard and the urgency for the EU and UK negotiators to agree on a sensible way forward.

\section{THE WITHDRAWAL AGREEMENT DOES NOT PROVIDE SUFFICIENT CLARITY}

The EU and the UK agreed on a revised Withdrawal Agreement on 17 October 2019 and the UK Parliament, after having rejected the previous version of the agreement on three occasions, passed it on 20 December 2019. The Withdrawal Agreement regulates the arrangements for the withdrawal of the UK from the EU and provides for a transition period

\footnotetext{
${ }^{3}$ Richard Aikens and Andrew Dinsmore, 'Jurisdiction, Enforcement and the Conflict of Laws in CrossBorder Commercial Disputes: What Are the Legal Consequences of Brexit?' (2016) 27(7) European Business Law Review 903, 908, Sara Masters

QC and Belinda McRae, 'What does Brexit Mean for the Brussels Regime?' (2016) 33 Journal of International Arbitration, Special Issue, 483, 492-494 and Andrew Dickinson, 'Back to the Future: The UK's EU Exit and the Conflict of Laws' (2016) 12 Journal of Private International Law 195, 201-203.
} 
during which EU law will continue to apply to and in the UK ("the Transition Period")." During this period, EU law is meant to produce the same legal effects in the UK as those which it produces within the EU and it shall be interpreted and applied in accordance with the same methods and general principles as those applicable within the EU. ${ }^{5}$ The Transition Period is set to end on 31 December 2020, ${ }^{6}$ although it may be extended for a period up to two years. ${ }^{7}$

In accordance with the terms of the Transition Period, the BIR (Recast) remains applicable to and within the UK as it did before Brexit (at least) until 31 December 2020. Moreover, it follows from Article 67(1)(a) of the Withdrawal Agreement that the provisions regarding jurisdiction of the BIR (Recast) will continue to apply to legal proceedings instituted before the end of the Transition Period as well as in respect of proceedings or actions related to such legal proceedings. Similarly, according to Article 67(2)(a) of the Withdrawal Agreement, the BIR (Recast) will also apply to the recognition and enforcement of judgments given in legal proceedings instituted before the end of the Transition Period (though seemingly not to proceedings or actions related to such legal proceedings).

Although the position is reasonably clear concerning the BIR (Recast), the position of the Lugano Convention 2007 and the Hague Convention during the Transition Period is, at a closer look, less evident. According to the Withdrawal Agreement, the continued application of EU law to the UK during this period includes international agreements to which the EU is a party. ${ }^{8}$ In particular, during the Transition Period, the UK shall be bound by the obligations stemming from international agreements 'concluded by the Union, by Member States acting on its behalf, or by the Union and its Member States acting jointly'? In an EU and UK perspective, the argument is that these international agreements would continue to operate as they do now, and that the UK would simply be treated as an EU Member State for the purposes of these agreements. In view of the requirements of the Withdrawal Agreement, it could be argued that nothing has changed in the perspective of third parties and that the agreements should continue to apply to the UK during the Transition Period.

However, although this solution may be acceptable to the EU and the UK, it is not certain that third parties will agree. According to Article 26 of the Vienna Convention on the Law of Treaties (VCLT), it is the EU that constitutes the contracting party and is as such bound by the agreement. Moreover, as provided for Article 34 VCLT, an international agreement cannot create rights and obligations for a third State without its consent. Thus, in an international law perspective, the UK does not continue to benefit from the Lugano Convention 2007 and the Hague Convention during the Transition Period since it has never been bound by either of the agreements in its own right under international law.

\footnotetext{
${ }^{4}$ Articles 126-127 of the Withdrawal Agreement.

${ }^{5}$ Article 127(3) of the Withdrawal Agreement.

${ }^{6}$ Article 126 of the Withdrawal Agreement.

7 Article 132 of the Withdrawal Agreement.

${ }^{8}$ Article 2(a)(iv) of the Withdrawal Agreement.

${ }^{9}$ Article 129(1) of the Withdrawal Agreement.
} 


\section{JURISDICTION AND THE ENFORCEMENT AFTER THE TRANSITION PERIOD - STILL CONSIDERABLE UNCERTAINTY}

It was noted in the introduction that an effective regime of jurisdiction and enforcement is important in order to maintain the attraction of the UK as a destination for cross-border disputes. Commercial parties might hesitate in designating English courts in jurisdiction clauses if they may not be respected in the EU, if there is a risk of parallel proceedings in the UK and an EU Member State respectively and if interim or final judgments of English courts are more difficult to enforce in the EU. Equally, the EU Member States have an interest in maintaining an efficient regime whereby issues related to jurisdiction and enforcement are regulated in order to provide certainty and efficiency for businesses and others engaged in cross-border transactions with the UK.

However, it is still uncertain how jurisdiction and enforcement between the UK and the EU Member States will be dealt with once the Transition Period has come to an end. The Political Declaration setting out the framework for the future relationship between the European Union and the United Kingdom (Political Declaration), a non-legally binding document setting out the framework for the future relationship between the EU and the UK, does not, unfortunately, provide much guidance. While it is stated that the parties should explore options for judicial cooperation in matrimonial, parental responsibility and other related matters, and that a new security partnership should comprise of judicial cooperation within criminal matters, foreign policy, security and defence and related areas, ${ }^{10}$ the Political Declaration is silent on future judicial cooperation. The lack of guidance is unfortunate. As we shall see, there is still considerable uncertainty surrounding the future application to the UK of existing EU and international arrangements.

\subsection{BIR (RECAST)}

The BIR (Recast) entered into force on 10 January 2015, ${ }^{11}$ replacing Council Regulation (EC) No 44/2001 on jurisdiction and the recognition and enforcement of judgments in civil and commercial matters [2000] OJ L12/1 (the Brussels I Regulation), and applies to all Member States, except Denmark, in accordance with EU law. ${ }^{12}$ However, as provided for in a separate agreement between Denmark and the EU, the regulation applies to the relations between the EU and Denmark under public international law. ${ }^{13}$ The UK has benefitted from the regulation as an EU Member State and remains subject to its regime during the Transition Period. However, as an EU regulation, the BIR (Recast) will not apply to the UK after the Transition Period.

Domicile is the primary connecting factor in the Brussels regime in order to establish jurisdiction. ${ }^{14}$ However, there are several exceptions to this general rule. For example, in

\footnotetext{
${ }^{10}$ Political Declaration, paras 56 as well as $79-82$ and 86-88 respectively.

${ }_{11}$ Proceedings instituted in EU Member States prior to 10 January 2015 are regulated by the Brussels I Regulation.

12 Denmark opted out from the home affairs and justice pillar through the Maastricht Treaty.

13 Agreement between the European Community and the Kingdom of Denmark on jurisdiction and the recognition and enforcement of judgments in civil and commercial matters.

${ }^{14}$ Article 4(1) BIR (Recast). The meaning of jurisdiction is governed by Articles 62 and 63 BIR (Recast).
} 
contract claims, the defendant may be sued in the place of performance of the obligation in question. ${ }^{15}$ Accordingly, in a claim arising out of a non-delivery of goods or services, the defendant could be sued in the country which delivery of the goods or the provision of services was meant to occur. Fundamentally, Article 25 BIR (Recast) governs all choice-ofcourt agreements. If the parties have agreed that a court of a Member State should have jurisdiction to settle a dispute, then, provided certain formalities are met, that court should have jurisdiction. ${ }^{16}$ Although this provision arguably also applies to non-exclusive jurisdiction agreements, ${ }^{17}$ Article 25 specifically provides that jurisdiction shall be exclusive unless the parties have agreed otherwise. Moreover, notably, it applies irrespective of the parties' domicile. Thus, if a party domiciled in Australia enter into a contract with a party domiciled in South Africa that includes a clause requiring any legal proceedings to be brought in London, this choice will be respected by the courts throughout the remaining EU-27.

The rules relating to lis pendens are found in Articles 29 to 31 BIR (Recast). Where proceedings involving the same cause of action and between the same parties are brought in the courts of different Member States, it follows from Article 29 that any court other than the court first seised shall of its own motion stay its proceedings until such time as the jurisdiction of the court first seised is established. However, this rule is expressly without prejudice to Article 31(2), which ensures that where a court of a Member State on which an agreement confers exclusive jurisdiction is seised, any court of another Member State must stay proceedings until such time as the court seised on the basis of the agreement declares that it has no jurisdiction under the agreement. Put differently, the court chosen by the parties will have priority regardless of which court was first seised. This is a notable change compared to the previous Brussels I Regulation, and related instruments such as the Lugano Convention 2007. Article 31(2) has accordingly reversed the CJEU's unfortunate decision in Case C-116/02, Gasser, and ended the notorious "Italian torpedo" procedure intended to cripple or sink legitimate proceedings founded on an exclusive jurisdiction clause. ${ }^{18}$ Another important addition brought on by the BIR (Recast) concerns choice-of-court agreements in favour of proceedings in a non-EU Member State. Provided certain conditions are fulfilled, Articles 33 and 34 BIR (Recast) now expressly permit a court in a Member State to stay proceedings in favour of a court in a state outside the EU in circumstances where proceedings are pending before the court of the third state when the EU Member State court is seised.

Alongside sophisticated rules on jurisdiction, the BIR (Recast) also provides a comprehensive regime on recognition and enforcement of judgments. As provided for in

\footnotetext{
15 Article 7(1) BIR (Recast).

${ }^{16}$ As set out in Article 25 BIR (Recast), there are certain conditions that have to be fulfilled. The only substantive prohibition, if those conditions are fulfilled, is if the jurisdiction agreement is held to be 'null and void as to its substantive validity' under the law of the state chosen to have jurisdiction. See further Aikens and Dinsmore (n 3), 913.

17 See for example Richard Fentiman, International Commercial Litigation, (2nd edn OUP, 2015) para 2.81. For support in the case law, see further Case C-23/78, Meeth v Glacetal EU:C:1978:198.

${ }^{18}$ In Case C-116/02, Gasser EU:C:2003:657, a case on the 1968 Brussels Convention, the CJEU gave priority to the lis pendens rule over exclusive choice-of-court agreements. That position prevailed under the Brussels I Regulation as well as the Lugano Convention 2007, neither of the instruments made any change to the text in this regard. The underlying principle, as stated by the CJEU, was that every Member State was equally competent to decide whether or not a choice-of-court agreement was valid and effective (Case C-116/02, Gasser EU:C:2003:657, para, 48).
} 
Article 36(1), a Member State is required to recognise a judgment in another Member State without imposing any special procedure. Moreover, as set out in Article 39, a Member State must also enforce a judgment without requiring a declaration of enforceability, provided the judgment is enforceable in the Member State where it is given. Accordingly, this means that the exequatur procedure common in civil law systems has been abolished, which is a notable improvement compared to previous enforcement rules. It should also be noted that the BIR (Recast) governs the availability of protective measures foreseen by the domestic law of each Member State, whether they are sought in support of a final judgment in the "exporting" Member State or on a provisional basis in support of ongoing proceedings in the "exporting" Member State. ${ }^{19}$

In theory, it may be possible for the UK to agree an international agreement with the EU similar to that agreed to by Denmark in order to continue to benefit from the BIR (Recast). This solution would have a number of significant advantages. ${ }^{20}$ The BIR (Recast) is generally considered to be the most advanced framework on jurisdiction and recognition and enforcement of judgements in civil and commercial matters and its rules, as broadly set out above, would continue to apply between the EU and the UK. However, the role of EU institutions accepted by Denmark in its agreement with the EU does not seem acceptable to the UK. Notably, Article 6(1) of the agreement between the EU and Denmark requires the latter to refer questions of interpretation concerning the BIR (Recast) to the CJEU. ${ }^{21}$ It is highly unlikely that the UK would want to agree to such obligations. ${ }^{22}$ Tellingly, in the UK government's document 'The Future Relationship with the EU', concerning the UK's approach to the negotiations on future relations with the EU, it is stated that:

'Whatever happens, the Government will not negotiate any arrangement in which the UK does not have control of its own laws and political life. That means that we will not agree to any obligations for our laws to be aligned with the EU's, or for the EU's institutions, including the Court of Justice, to bave any jurisdiction in the UK'. ${ }^{23}$

Accordingly, the BIR (Recast), despite its advantages, does not seem to be a viable option for a future arrangement between the EU and the UK. It should be noted that a decision to apply the BIR (Recast) unilaterally is not an alternative. It does not work well for jurisdiction and it does not work at all for recognition and enforcement of judgments; the regulation rests on a principle of reciprocity.

\footnotetext{
19 Articles 35 and 40 BIR (Recast) respectively. Pre- and post-judgment relief is not new, see for example Articles 31 and 47 respectively of the Lugano Convention 2007.

20 See further Masters and McRae (n 3), 485-487.

${ }^{21}$ It should be noted that Article 6(2) of the agreement requires Denmark to give "due account" to CJEU decisions when applying the BUR (Recast). This is similar to the interpretative requirement provided for in the 2007 Lugano Convention. See further text to n 28 below.

22 There may be further difficulties to consider if the UK would want to continue to be subject to the BIR (Recast). For example, according to Article 5(2) of the agreement between the EU and Denmark, the latter nay not enter into international agreements which may affect or alter the scope of the BIR (Recast) without the agreement of the EU. See further Aikens and Dinsmore (n 3), 914-915.

${ }^{23}$ UK government, 'The Future Relationship with the EU', para 5 (emphasis added).
} 


\subsection{LUGANO CONVENTION 2007}

As the successor to the Lugano Convention 1988, the Lugano Convention 2007 was signed by the EU as well as Iceland, Norway and Switzerland and entered into force on 1 January 2010. ${ }^{24}$ Accordingly, the UK has been covered by this international agreement in accordance with its EU membership and is not a contracting party in its own right. ${ }^{25}$ As considered above, the UK is not a party to international agreements entered into by the EU alone, including the Lugano Convention 2007, after Brexit.

Similar principles that apply to the BIR (Recast) also govern the Lugano Convention 2007. However, as with the predecessor the BIR (Recast), the Brussels I Regulation, the scope of the convention is narrower in some important respects. For example, concerning jurisdiction, it follows from Article 23(1) that an exclusive jurisdiction clause shall be recognised by the courts of the contracting parties only if at least one of the parties is domiciled in a State bound by the convention. Accordingly, in contrast to the BIR (Recast), in circumstances where neither of the parties is domiciled in a State bound by the Lugano Convention 2007, the latter does not require the chosen court to accept jurisdiction. In such cases, whether to accept jurisdiction is a matter for the chosen court and its domestic conflict of laws rules. ${ }^{26}$

In addition, the lis pendens rule in Article 27 of the Lugano Convention 2007 applies to the court first seised and is not subject to any exception. Thus, as opposed to the improved BIR (Recast), the court chosen by the parties will not necessarily have priority regardless of which court was first seised. Consequently, as noted above, torpedo actions initiated before a court of another contracting party than that specified in an exclusive jurisdiction clause cannot be avoided under the Lugano Convention 2007. Moreover, the discretion introduced in Articles 33 and 34 BIR (Recast) to stay proceedings where there are identical or related proceedings in a third State is not found in the Lugano Convention 2007.

Further, regarding enforcement, a State bound by the Lugano Convention 2007 is required to recognise a judgment from another Member State without imposing any special procedure. ${ }^{27}$ However, as required by Article 38(1), a judgment given in a State bound by the convention shall only be enforceable in another State bound by the convention provided it has been declared enforceable there. ${ }^{28}$ As noted above, in order to simplify the process of enforcement, this exequatur procedure is not included in the BIR (Recast).

The relationship between the courts of the contracting parties and the CJEU is dealt with in a separate protocol, Protocol 2. As its Preamble explains, the protocol seeks to reduce divergent interpretations as between the Brussels I Regulation and the Lugano Convention 2007. Because the Protocol is directed at non-EU Member States and operates as part of a multilateral regime, its provisions are more nuanced than the Denmark-EU Agreement

\footnotetext{
${ }^{24}$ It entered into force on 1 January 2011 for Switzerland and on 1 May 2011 for Iceland.

25 Article 216(2) TFEU.

26 The Lugano Convention 2007 does not leave this situation entirely unregulated. As provided for in Article 23(3), courts of other States bound by the Lugano Convention 2007 will not have jurisdiction over disputes where none of the parties is domiciled in a State bound by the convention, unless the chosen court has declined jurisdiction.

27 Article 33(1) of the Lugano Convention 2007.

28 As provided for in Article 39(1) and Annex II of the Lugano Convention 2007, the application shall be submitted to certain specified courts; in England and Wales it is normally the High Court of Justice, in Scotland generally the Court of Session and in Northern Ireland usually the High Court of Justice.
} 
considered above. In particular, Article 1(1) of the protocol requires courts applying and interpreting the convention to "pay due account" to relevant decisions of the CJEU, as well as the courts of other states bound by the convention. This obligation applies not only to provisions of the Lugano Convention 2007, but also to the Lugano Convention 1988 as well as the Brussels Convention and the Brussels I Regulation. ${ }^{29}$

Is the Lugano Convention 2007 a feasible alternative as to regulate the relationship between courts in EU Member States and the UK after the Transition Period? In view of the similarities to the BIR (Recast), it would provide stability and certainty if the UK were to accede to the Lugano Convention 2007. However, the parallelism that exists between the Brussels and Lugano instruments and the influence of the CJEU may, at first sight at least, seem incompatible with the UK's approach towards the CJEU and the obligation to take account of judgments of a foreign court. Yet, on 8 April 2020, the UK submitted its application to accede to the Lugano Convention 2007. Its application follows the support received in January 2020 from Norway, Iceland and Switzerland to accede to the convention following the end of the Transition Period. ${ }^{30}$ However, to join the 2007 Lugano Convention cannot be done unilaterally, or with the support by some, or the majority, of the contracting parties. As provided for in Article 72 of the Lugano Convention 2007, in addition to fulfilling the necessary criteria, the UK is only able to accede if all contracting parties unanimously agree to it. ${ }^{31}$ It is far from certain that the EU is ready to provide the necessary support, such a move is likely to be dependent on the negotiations between the parties at large.

In the event there would be unanimous agreement to allow the UK to accede to the Lugano Convention 2007, the convention would enter into force in relation to the UK, at the very earliest, on the first day of the third month following the unanimous decision by the other contracting parties. ${ }^{32}$ Accordingly, if the EU would agree to the UK becoming a member before 1 November 2020, the Lugano Convention 2007 could become applicable on 1 January $2021 .{ }^{33}$ However, even in this scenario, the status of the UK would not necessarily provide the legal certainty hoped for. As discussed above, although the EU and the UK continue to treat the UK as bound by the international agreements entered into by the EU during the Transition Period, the UK is not a party to the Lugano Convention 2007 as a matter of international law. The UK would only be bound by the rules of the Lugano Convention 2007 from the moment the convention would enter into force in relation to the UK as a contracting party, thus possibly from 1 January 2021.

As set out in Article 63(1) of the Lugano Convention 2007, the convention only applies to legal proceedings instituted after the entry into force in the State where a judgment originates from and in the State where recognition or enforcement of a judgment is sought. However, Article 63(2) provides for an exception to this rule. If the proceedings in the state

${ }^{29}$ Article 1(1) of Protocol 2 of the 2007 Lugano Convention illustrates the principle of parallelism that has guided the parties to the Brussels and Lugano regimes to ensure the conformity between the Brussels and Lugano instruments.

30 UK government, 'Support for the UK's intent to accede to the Lugano Convention 2007'

$<$ (https://www.gov.uk/government/news/support-for-the-uks-intent-to-accede-to-the-lugano-convention2007) accessed 7 May 2020> .

31 This requirement would not apply if the UK became a member of the European Free Trade Association

(Article 71 of the 2007 Lugano Convention).

32 Articles 72(3)-(4) of the Lugano Convention 2007.

${ }^{3}$ It would be contrary to the Withdrawal Agreement for the UK to apply the 2007 Lugano Convention as a party in its own right before the end of the Transition Period (Article 129(4) of the Withdrawal Agreement). 
of origin were instituted before the entry into force of the Lugano Convention 2007, judgments given after its entry into force must be recognised and enforced in accordance with the rules of the convention, provided one of two alternative conditions is fulfilled. First, if the proceedings in the state of origin were instituted after the entry into force of the Lugano Convention 1988 both in the state of origin and in the state addressed, or, second, if jurisdiction was founded upon rules which "accorded with" those provided for in the Lugano Convention 2007 or in a convention concluded between the state of origin and the state addressed which was in force when the proceedings were instituted.

It may well be argued that the UK would fulfil both these conditions. In particular, although the UK has not been covered by the Lugano Convention 2007 as a matter of international law after Brexit on 31 January 2020, the UK has been bound by this convention as well as the BIR (Recast) in accordance with its obligations as an EU Member State prior to that date and, during the Transition Period, it has been subject to the BIR (Recast) as well as the rules of the Lugano Convention 2007 as provided for in the Withdrawal Agreement. The parallelism between the Lugano Convention 2007 and the BIR (Recast) means that the UK has continuously, prior to the 1 January 2021, been bound by rules which have "accorded with" those set out in the Lugano Convention 2007.

However, the transitional provisions of the Lugano Convention 2007 alongside those of the Withdrawal Agreement do not provide for all situations. As considered above, under the Withdrawal Agreement, the BIR (Recast) remains applicable during the Transition Period and continues to apply after the Transition Period, provided legal proceedings were instituted before the end of the Transition Period. It follows that a situation where a jurisdiction clause designates UK courts under a choice of court agreement entered into before the end of the Transition Period, but where legal proceedings are instituted after the Transition Period, could become problematic. Even if the UK would accede to the Lugano Convention 2007 on 1 January 2021, the convention will not apply to such a choice-of-court agreement. Nor will the BIR (Recast) apply since legal proceedings have been instituted after the end of the Transition Period. Accordingly, in this scenario, courts in EU Member States would not be required to stay proceedings in favour of the designated UK courts under the Lugano Convention 2007 or the BIR (Recast).

It may perhaps be argued, in view of the requirement in the Withdrawal Agreement to continue to apply international agreements entered into by the EU to the UK during the Transition Period, that EU Member State courts have an obligation under the Withdrawal Agreement to apply the rules of the Lugano Convention 2007 in this situation. The rationale for this argument would be that the UK is treated as an EU Member State for the purposes of EU law (including international agreements entered into by the EU) during the Transition Period and the UK should therefore be in no worse position as regards jurisdiction clauses agreed during this period. On the other hand, it is the BIR (Recast) that governs the relationship between courts of the EU Member States and the UK during the Transition Period. The Lugano Convention 2007 is not applicable. The EU and the UK have specifically agreed in the Withdrawal Agreement in what circumstances the BIR (Recast) would apply after the Transition Period. As considered above, the BIR (Recast) does not apply if legal proceedings are instituted after the end of the Transition Period. 


\subsection{HAGUE CONVENTION}

The Hague Convention is an international agreement that entered into force on 1 October 2015, to which the EU is a party (Denmark is a party in its own right) alongside Mexico, Montenegro and Singapore. ${ }^{34}$ As set out in Article 1(1), it applies to exclusive choice of court agreements in international cases in civil and commercial matters. ${ }^{35}$ Consumer and employment contracts, alongside other types of contracts, are expressly excluded from its application. ${ }^{36}$ Similarly to the Lugano Convention 2007, the UK has been covered by the Hague Convention only in accordance with its EU membership. As an international agreement entered into by the EU alone, the UK is covered by thus agreement as a matter of international law after Brexit.

The essence of the Hague Convention is set out in three basic rules. First, pursuant to Article 5, the chosen court in an exclusive choice of court agreement shall have jurisdiction to decide a dispute which falls within its purview and cannot as a general rule decline to exercise its jurisdiction. ${ }^{37}$ Second, as provided for in Article 6, except for certain specific circumstances, courts in other states bound by the convention that have not been chosen are required to suspend or dismiss proceedings brought before them. Third, it follows from Article 8 that non-chosen courts must both recognise and enforce a decision by the court chosen by the parties without review of the merits of the judgment. In addition to these three basic principles, the rule on non-exclusive jurisdiction agreements in Article 22 must also be recognised as an important characteristic of the convention. According to this provision, a contracting state may declare that it will recognise and enforce judgments given by courts of another contracting State. ${ }^{38}$

Although the Hague Convention constitutes a comprehensive regime on jurisdiction, recognition and enforcement of judgments amongst its contracting parties, this convention is a far less developed tool than both the BIR (Recast) and the Lugano Convention 2007. There are significant shortcomings to consider, particularly in comparison with the BIR (Recast). Its restriction to exclusive jurisdiction agreements is an obvious limitation. Moreover, as expressly set out in Article 7, the Hague Convention does not apply to interim

\footnotetext{
34 The US, China, Ukraine and the Republic of North Macedonia have signed the Hague Convention, but they have not yet ratified it.

35 The definition of what is an international case differs between jurisdictional issues (Chapter II) and recognition and enforcement issues (Chapter III). For the convention's jurisdictional rules to apply, a case is international unless the parties are resident in the same Contracting State and the relationship of the parties and all other elements relevant to the dispute, regardless of the location of the chosen court, are connected only with that State (Article 1(2) of the Hague Convention). For the purposes of obtaining recognition and enforcement of a judgment in a contracting State, it is sufficient that the judgment presented is foreign (Article 1(3) of the Hague Convention).

36 Articles 2(1)-(2) of the Hague Convention

${ }^{37}$ As provided for in Article 3(b) of the Hague Convention, all choices of jurisdiction are presumed to be exclusive unless they are expressly stated to be otherwise. Notably, asymmetric jurisdiction clauses - choice of court agreements drafted to be exclusive as regards proceedings brought by one party but not as regards proceedings brought by the other party - is not considered to be an exclusive jurisdiction clause for the purposes of the convention (Trevor Hartley and Masato Dogauchi, 'Explanatory Report on the 2005 Hague Choice of Court Agreements Convention', paras 105-106. Moreover, Article 19 of the convention provides for an exception to the rule that a designated court cannot decline to exercise jurisdiction. A State may declare that its courts may refuse to determine disputes to which an exclusive choice of court agreement applies if, except for the location of the chosen court, there is no connection between that State and the parties or the dispute.

${ }^{38}$ Where no choice is made by the parties, the convention simply does not apply.
} 
measures. Also, although non-chosen courts are required to both recognise and enforce a decision of a designated court, the convention leaves the process of doing so to the State where recognition and enforcement take place. Accordingly, in contrast to the BIR (Recast), the Hague Convention allows for an exequatur procedure. ${ }^{39}$

Despite its more limited application, the Hague Convention constitutes an important alternative means by which certainty could be provided to parties in the EU and UK respectively. In contrast to the Lugano Convention 2007, the Hague Convention is open to all states without any requirement of acceptance by other contracting parties. ${ }^{40}$ The UK has the intention to accede to the convention and deposited its original application to do so on 28 December 2018, declaring that the UK would accede to the Hague Convention in its own right with effect from 1 April 2019. However, with the entry into force of the Withdrawal Agreement, there has not been a need for the UK to accede to the Convention during the Transition Period. Instead, the UK has signalled that it will deposit a new instrument of accession at the appropriate time prior to the termination of the Transition Period. According to Article 31(1), the Hague Convention takes effect on the first day of the month that follows a period of three months after ratification. Provided that the Transition Period ends on 31 December 2020, this means that the UK must deposit its new instrument of accession by the end of September 2020 in order to accede to the convention on 1 January 2021.

However, similarly to the Lugano Convention 2007, the status of the UK in relation to the Hague Convention does not necessarily provide the legal certainty hoped for. As discussed above, although the EU and the UK continue to treat the UK as bound by the international agreements entered into by the EU during the Transition Period, the UK is not a party to the convention. Further, according to Article 16, the Hague Convention shall only apply to exclusive choice-of-court agreements concluded after its entry into force for the State of the chosen court. Consequently, if the UK were to accede to the Hague Convention on 1 January 2021, the rules of the convention would only apply to exclusive UK jurisdiction clauses entered into after that date. Moreover, as also considered above, the BIR (Recast) continues to apply after the Transition Period only if legal proceedings have been instituted before the end of this period.

It follows that a situation where an exclusive jurisdiction clause designates UK courts under a choice-of-court agreement entered into before the end of the Transition Period, but where legal proceedings are instituted after the Transition Period, is not covered by either the BIR (Recast) or the Hague Convention (or, as considered above, the Lugano Convention 2007), even if the UK would accede to the latter on 1 January 2021. Accordingly, courts in EU Member States will not be required to stay proceedings in favour of the designated UK courts under the Hague Convention or the BIR (Recast). ${ }^{41}$

\footnotetext{
39 Article 39 BIR (Recast).

40 Article 27 of the Hague Convention.

${ }^{41}$ Similarly to the Lugano Convention 2007, it could be argued that EU Member State courts have an obligation under the Withdrawal Agreement to apply the rules of the Hague Convention in this situation, in accordance with the requirement in the Withdrawal Agreement whereby the UK continues to be bound by obligations stemming from international agreements entered into by the EU during the Transition Period (Article 129(1) of the Withdrawal Agreement). However, as underlined above, it is the BIR (Recast) that governs the relationship between courts of the EU Member States and the UK during the Transition Period. The Hague Convention is not applicable. The EU and the UK have specifically agreed in the Withdrawal
} 
It should be noted that UK courts faced with an exclusive jurisdiction clause designating a court in an EU Member State under a choice-of-court agreement entered into before the end of the Transition Period, but where legal proceedings are instituted after the Transition Period, are in a different position under the Hague Convention than courts in EU Member States in corresponding circumstances. As underlined above, the Hague Convention applies to exclusive choice of court agreements concluded after its entry into force for the State of the chosen court. Accordingly, contracting states should apply the Hague Convention to enforce judgments pursuant to exclusive jurisdiction clauses in favour of other contracting states, as long as the Hague Convention was in force for the chosen State at the time the clause was entered into. It does not matter, at that time, whether the convention was in force in the country of enforcement, provided it is in force by the time enforcement proceedings are brought. Accordingly, there is an element of asymmetry in the Hague Convention; a new contracting State must apply it retrospectively to clauses in favour of existing members, provided the clause was agreed after the Hague Convention entered into force for that State, whereas existing members will only apply the Hague Convention prospectively as far as clauses in favour of a new contracting State are concerned.

\subsection{BRUSSELS CONVENTION}

The Brussels Convention was concluded as an international agreement in 1968 by the original six members of the EU (then the EEC). Its object was to facilitate the enforcement of judgments in civil and commercial matters amongst Member States. A protocol concluded in 1971 gave the European Court of Justice (now CJEU) jurisdiction to interpret the Brussels Convention. Amendments were made to the convention in 1978 at the time that the UK, alongside Ireland and Denmark, entered into an Accession Convention with the original six Contracting Parties. Further amendments to the Brussels Convention were made as other countries acceded to the EU (then the EC and subsequently the EU). ${ }^{42}$ The Brussels Convention was followed by the Brussels I Regulation but was never formally cancelled after the entry into force of the regulation.

As noted in the introduction, it has been argued that the Brussels Convention has not been terminated as a matter of public international law and that, upon Brexit, the Brussels Convention would revive between the UK and the Member States. The argument circles around Article 68 of the Brussels I Regulation, ${ }^{43}$ which provides that '[Brussels I Regulation] shall, as between the Member States, supersede the 1968 Brussels Convention [...]' (emphasis added). According to Aikens and Dinsmore, this wording does not evince an intention impliedly to terminate the Brussels Convention but rather to suspend its application for so long as the Brussels I Regulation, and subsequently the BIR (Recast), applies. ${ }^{44}$ Thus, pursuant to this view, the BIR (Recast) will take precedence over the Brussels Convention as long as the parties to the convention are also subject to the regulation. In support of this argument it is also underlined that recital 23 of the Brussels I Regulation provides that the

\footnotetext{
Agreement in what circumstances the BIR (Recast) should apply after the Transition Period. As considered above, the BIR (Recast) does not apply if legal proceedings are instituted after the end of the Transition Period.

42 In particular, see Aikens and Dinsmore (n 3), 906-907.

43 Article 68 of the Brussels I Regulation corresponds to Article 68 BIR (Recast).

${ }^{44}$ Aikens and Dinsmore (n 3) 908. See also Dickinson (n 3), 201-203 and Masters and McRae (n 3) 492-494.
} 
Brussels Convention continues to apply to certain territories of the Member States that are not within the scope of regulation. ${ }^{45}$ Masters and McRae consider this to strengthen the argument that the convention has not been terminated and remains intact. ${ }^{46}$

However, there are difficulties with the view that the Brussels Convention has been revived due to Brexit. First, the terms 'shall [...] supersede' are out of step with other language versions of the Brussels I Regulation and do not adequately reflect the meaning of Article 68 BIR (Recast). For example, the French language version uses the term 'remplace', the German 'tritt [...] an die Stelle', the Italian 'sostituisce', the Swedish 'ska [...] ersätta' and the Danish 'træder [...] i stedet for'. Accordingly, in order for the English language version to reflect what the true meaning of Article 68 of the Brussels I Regulation, it would have been more accurate to use the terms 'shall [...] replace' (or possibly 'shall [...] substitute') instead of 'shall [...] supersede'. The wording 'shall replace' suggests that the Brussels Convention was terminated by the Brussels I Regulation, not simply temporarily displaced. Second, recital 23 of the Brussels I Regulation must be read alongside recital 21 and, in particular, recital 22. The latter refers to the special position enjoyed by Denmark as a nonparticipant in the Brussels I Regulation and provides:

'Since the Brussels Convention remains in force in relations between Denmark and the Member States that are bound by [the Brussels I Regulation], both the Convention and the 1971 Protocol continue to apply between Denmark and the Member States bound by [the Brussels I Regulation],. ${ }^{47}$

Accordingly, the reason the Convention would continue to apply between Denmark and the other Member States at the time of the adoption of the Brussels I Regulation was because Denmark did not participate in the adoption of the Brussels I Regulation and the Brussels Convention therefore continued to be 'in force' as between Denmark and the other Member States. With the use of the terms ' $\mathrm{t}$ ] he Brussels Convention also continues to apply to' (emphasis added), recital 23 refers back to recital 22. Thus, the Brussels Convention continues to apply to certain territories of the Member States that are not within the scope of the Brussels I Regulation because the convention remains in force in this regard. It is not merely a question of to which territories the Brussels Convention applies or is temporarily disapplied. In accordance with Article 68 of the Brussels I Regulation, as discussed above, the Brussels Convention was terminated and replaced by the Brussels I Regulation as between the Member States, but for the areas singled out in recitals 22 and 23.

Third, the Brussels Convention was never meant to apply to non-EU Member States. It follows from the preamble that the purpose of the convention was to strengthen the legal protection of persons established in the EU (then EEC). The original contracting parties were all EU (then EEC) Member States and Article 63 of the convention made it a requirement for all future EU Member States to join.

Notably, similar arguments as those presented above about the revival of the Brussels Convention could be raised in respect of the Lugano Convention 1988 since it was agreed to by the UK in its own right, alongside the other then existing EU Member States. However,

\footnotetext{
${ }^{45}$ Recital 23 Brussels I Regulation corresponds to recital 9 BIR (Recast).

46 Masters and McRae (n 3) 493.

47 (emphasis added).
} 
it is commonly agreed that the arguments in favour of a revival of this convention have less prospect of success. ${ }^{48}$ Primarily, the English language version of Lugano Convention 2007, the successor of the Lugano Convention 1988, is clearer. According to the wording of the Article 69(6) of the Lugano Convention 2007, this convention "shall replace" the Lugano Convention 1988. Moreover, the Lugano Convention 1988 does not continue to apply with regard to certain territories, accordingly it does not create any ambiguity in this respect.

It should be recognised that public international law conventions concerning the effect of treaties ${ }^{49}$ do not deal specifically with the question of whether one treaty is impliedly terminated where a supra-national body such as the EU has formed a new instrument on behalf of its Member States, with the intention that this new instrument should 'replace' a previously concluded international treaty entered into by some of the member States of the supra-national body. ${ }^{50}$ However, Article 54(b) of the VCLT provides that the termination of a treaty may take place at any time by consent of all the parties. The EU has assumed exclusive competence in matters of jurisdiction and the recognition and enforcement of judgments in civil and commercial matters. ${ }^{51}$ Put differently, the Member States have voluntarily provided the EU with their competence to act within these matters. Arguably, with the adoption of the Brussels I Regulation by the EU, the EU Member States (including Denmark, in accordance with the EU-Denmark agreement) have at least implicitly agreed to terminate the Brussels Convention. There is nothing in the Brussels Convention that required the Member States to terminate the convention by a certain procedure.

In any event, the Brussels Convention has been marginalised in favour of modified instruments, namely the Brussels I Regulation and subsequently the BIR (Recast), with changes made to remedy what were seen as being flaws in the original architecture. ${ }^{52}$ Moreover, even if the Brussels Convention would be considered still applicable, it is doubtful if all EU Member States would be covered by the convention, thus its territorial application would be significantly reduced. In addition, according to a separate protocol also accepted by the UK, the Brussels Convention is subject to the interpretation of the CJEU. ${ }^{53}$ As discussed above, this is hardly a palatable option for the UK.

\section{CONCLUDING REFLECTIONS}

It would be wrong to think that the UK will lose its status as a leading centre for international commercial litigation after Brexit. There are important reasons why London is a destination of choice for international litigation that will not be (at least directly) affected by Brexit. For example, the reputation and experience of English judges, English law as the prevalent choice of applicable law in international commercial transactions, the efficiency of remedies available under English law, the procedural effectiveness of the English Courts and the

48 See for example Aikens and Dinsmore (n 3), p. 912, Dickinson (n 3), pp. 203-204 and Masters and McRae (n 3) 4.

49 Including the VCLT and the Vienna Convention on the Law of Treaties between States and International Organisations public international law conventions concerning the effect of treaties.

${ }^{50}$ See further Dickinson (n 3) 204.

51 See further Opinion 1/03, The new Lugano Convention EU:C:2006:81.

52 With the entry into force of the Lugano Convention 2007, the same is true for the Lugano Convention 1988.

${ }^{53}$ Protocol concerning the interpretation by the Court of Justice of the Convention of 27 September 1968 on jurisdiction and the enforcement of judgments in civil and commercial matters. 
neutrality, independence and impartiality of the judiciary. Moreover, it is difficult to escape the fact that the English language is the lingua franca of international commerce.

However, a key component of a jurisdiction's international competitiveness is the extent to which its courts' judgments will be recognised and enforced internationally. If the $\mathrm{EU}$ and the UK are not able to agree on common rules in this regard, judgments of the remaining EU Member States may still be recognised and enforced in the UK and vice versa under the unilateral private international law recognition and enforcement rules of each relevant country. But the application of national rules is generally more complicated than a common framework. In this perspective, a return to unilateralism in the UK is not a benefit and it is unlikely to promote London as a legal centre and venue. ${ }^{54}$ Common EU-UK rules on jurisdiction and enforcement in order to promote and assist cross-border litigation involving UK courts or litigants is therefore in the interest of the UK. Such a framework, promoting stability and access to justice, is of course also of significance to businesses and individuals in the EU with interests related to the UK.

The BIR (Recast) has evolved through the application of both the Brussels and Lugano regimes, with the result that it has advanced into a sophisticated instrument used in all EU Member States. In view of the UK government's unwillingness to grant the CJEU jurisdiction in the UK, it is highly unlikely that the UK would want to apply the regulation as a matter of an international agreement similarly to Denmark. However, it is encouraging that the UK government has applied to accede to the Lugano Convention 2007. In view of the existing parallelism between the Brussels and Lugano regimes, the result would be that there would not be any major changes from the current regime in relation to jurisdiction and enforcement, so that English (UK) court judgments would continue to be readily enforceable throughout the EU and in EFTA countries, and English jurisdiction clauses would largely be respected by those countries, and vice versa. With that said, there are disadvantages with the Lugano Convention 2007 - it lacks the improvements brought on by the BIR (Recast). Notoriously, the 2007 Lugano Convention leaves parties at liberty to resort to forum optimisation tactics and choose the forum that may be most appropriate to their case or most inconvenient for the adverse party.

While the UK's intention to join the Lugano Convention is welcome, it is not at all certain that the unanimous agreement needed to accede is forthcoming in the near future. While Iceland, Norway and Switzerland have indicated their support for the UK's accession, the EU's position is at the time of writing not yet clear. In view of the ongoing negotiations between the parties and the unwillingness of the UK to participate in the internal market, the EU (including Denmark as an independent State) may well hesitate in agreeing to the UK's application. If the UK is unable to accede to the Lugano Convention 2007 when the Transition Period comes to an end, the Hague Convention appears to be the most straightforward solution, in particular since there is no need for approval of any other contracting party to sign and ratify the convention. However, the more limited nature of the Hague Convention would mean a significantly less advanced instrument than what is currently available. For example, first, the Hague Convention only applies where there is an

\footnotetext{
${ }^{54}$ Jan Dalhuisen, "Recognition of civil and commercial judgments if the UK reaches "exit day" without a new arrangement in place' (2017) 10 Journal of International Banking and Financial Law 646, 647.
} 
exclusive jurisdiction agreement, and, second, in contrast to the BIR (Recast), the Hague Convention leaves the process of enforcement to the enforcing State.

Finally, one option that was not discussed above is of course for the UK and the EU to negotiate a new arrangement on civil jurisdiction and judgments. However, such an exercise would be time-consuming and it is unlikely for such an option to become a reality prior to the end of the Transition Period, which is, under the now existing time table, only months away. Still, it is reasonable to believe that there will be continued negotiations between the $\mathrm{EU}$ and the UK also after the (possible) entry into force of a new agreement, or indeed agreements, between the parties on 1 January 2021. Hopefully, such negotiations will result in continued development of any arrangement on civil jurisdiction and judgments, be it an update of the Lugano Convention 2007 or the establishment of something new. This would benefit both the UK and the EU Member States. 


\section{LIST OF REFERENCES}

Aikens R and Dinsmore A, 'Jurisdiction, Enforcement and the Conflict of Laws in Cross-Border Commercial Disputes: What Are the Legal Consequences of Brexit?' (2016) 27(7) European Business Law Review 903

Dalhuisen J, 'Recognition of civil and commercial judgments if the UK reaches "exit day" without a new arrangement in place' (2017) 10 Journal of International Banking and Financial Law 646

Dickinson A, 'Back to the Future: The UK's EU Exit and the Conflict of Laws' (2016) 12 Journal of Private International Law 195

DOI: https://doi.org/10.1080/17441048.2016.1209847

Fentiman R, International Commercial Litigation (2nd edn Oxford University Press, 2015)

Masters S and McRae B, 'What does Brexit Mean for the Brussels Regime?' (2016) 33 Journal of International Arbitration, Special Issue, 483 